\title{
Cahit Sıtkı Tarancı Şiiri ve Örnekler Işı̆̆ında Almancaya Çevrilebilirliği Üzerine Bir İrdeleme
}

\author{
Dr. Öğr. Üyesi Rahman Akalın \\ Trakya Üniversitesi, Edebiyat Fakültesi \\ Mütercim-Tercümanlık Bölümü \\ rahmanakalin@trakya.edu.tr
}

Öz

Cahit Sıtkı, Türk Edebiyatı'nın az sözcükle çokça duyguyu ifade edebilmiş şairlerindendir. Bu başarıyı yalnızca seçtiği sözcüklerdeki anlam yükü ile değil, şiirlerindeki kurgu ile sağlayabilmiştir. Çeviri odaklı değerlendirildiğinde, ruhu ve anlatımından bağımsız olarak, şiir çevirisi çevirmenleri belli oranda şair gibi düşünmeye, bunun da ötesinde şair gibi eylemeye itmektedir. Bu bağlamda şiir çevirisi özellikle birbirine çok yakın olmayan kültür dizgeleri arasında, çoğu zaman zor, hatta başarısızlı̆̆a uğramaya mahkûm bir girişim olarak tanımlanmıştır. Bu çalışmada Cahit Sıtkı Tarancı şiirlerinin genel özellikleri betimlenmeye çalışılmış, çevirileri Işık Aygün tarafından yapılmış olan 'Yıldızlar' ve 'Dalgın Ölü' adlı Tarancı şiirleri bu çerçeve içerisinde çözümlenmiş ve bu şiirlerin Almancaya çevirileri eleştirel açıdan mercek altına alınıp değerlendirmelerde bulunulmuştur. İnceleme sonunda, Cahit Sıtkı'nın gerek biçim gerekse içerik açısından kendine özgü bir şiirselliği sürdürmüş olduğu, seçilen örnekler temelinde bu şiirselliğin kabul edilebilir çeviri sonuçlarını ortaya koyduğu bulgulanmıştır.

Anahtar Kelimeler: Cahit Sıtkı Tarancı, Yıldızlar, Dalgın Ölü, yazın çevirisi, şiir çevirisi.

\section{Cahit S1tkı Taranc1 Poetry and an Investigation on the Translation into German in the Light of Examples}

\section{Abstract}

Cahit Sitk1 is one of the poets of Turkish literature who can express a lot of emotion with little words. He was able to achieve this success not only by the meaning burden in his chosen words but also by his fiction in his poems. Regardless of the spirit and expression of translation, poetry translation pushes translators to think in a certain proportion like poets; moreover, to behave like them. In this context, the translation of poetry is defined as an attempt that is mostly difficult and even doomed to failure among the cultural systems that are not very close to each other. In this study, the general features of Cahit Sitkı Taranc1 poems have been attempted to be described. Taranc1 poems which are called 'Yıldizlar 'and 'Dalgın Ölü', translated by Işık Aygün, have been analyzed within this framework and the translation of these poems into German has been examined critically and evaluated. At the end of the study, it has been found that Cahit Sttk had maintained his own poetic style in terms of both form and content, and this poetry showed acceptable translation results on the basis of selected examples.

Keywords: Cahit Sıtkı Tarancı, Yıldızlar, Dalgın Ölü, literary translation, poetry translation. 


\section{GíRIŞ}

Cahit Sıtkı Tarancı, Türk Edebiyat Dizgesi içerisinde ölüm temasını çarpıcı şekilde ele aldığı '35 Yaş' şiiri ile geniş kitlelere dokunmuş, şiirlerinde kötümser ögelerle iyimser ögeleri ustaca harmanlayan, iyi ile kötüyü, sözüm ona güzel ile çirkini bir kutupluluk üzerinden anlatmayı denemiş bir şairdir. Bu kutupluluk anlayışı, karşıtların birbirini gerektirdiği diyalektik bir çerçeve açısından makul olduğu gibi, bir açıdan da son derece gerçekçidir. Zira gerçek hayatın bir öykünmesi olarak paralel bir gerçeklik yaratan edebiyat, gerçek hayatın bir izdüşümüdür. Gerçek hayatta ise iyi ile kötü yan yana durabilmektedir. Günlük hayatlarımız ise idealize bir çerçeve içerisinde hareket ettiğimiz düzenler değildir.

Cahit Sıtkı' da yalnızlık ('Ömrümde Sükût', örn. burada incelenen 'Yıldızlar'), ölüm ('Sanatkârın Ölümü', örn. burada incelenen 'Dalgın Ölü') ve bu dünyadan kaçış ('Yıldızlar', 'Bir Kapı Açıp Gitsem') temaları ön plandadır. Ancak Samanoğlu'nun (1971, s. IX) tespitlerine göre Cahit Sıtkı, "temalarında [...] değişik açılar kullanır ve en ince ayrıntıları bulur. Nitekim bunları ['Çilingir Sofrası' şiirinde görülddüğü gibi] 'aşk', 'içki', 'geçmiş zaman', 'çocukluk yıllarının özlemi' ve daha birçok konu tamamlar". İnsanın nesneler karşısındaki konumu, onlarla ilişkisi, soru işaretleri uyandıran bir üslup ile işlenir. "'Eşya', 'insan'la mana kazanan 'hayat' içinde önemlidir. 'Ölüm'e, 'yaşama sevgisi'yle ve onun sembolleriyle savaş açar. Bu yüzden 'ölüm'de bile, 'yaşama isteği' hâkimdir."

Çalışmada benzer temaları ve özünde bir kutupluğu işleyen iki Tarancı şiiri, 'Yıldızlar' ve 'Dalgın Ölü' şiirlerini içeren çeviri durumları ve Cahit Sıtkı'nın şiirindeki özellikler ışığında, özgünler ve çeviri metinler içkin olarak C. Nord'un (1988) çeviri odaklı metin çözümlemesi yaklaşımı esas alınarak çözümlenmiş ve veriler karşılaştırmalı olarak ortaya konmuştur. Çözümlemeden doğan veriler ışığında karşılaştırmalar yapılmış ve özgünleri ile çeviri metinler çeviri-eleştirel açıdan irdelenmeye çalışılmıştır.

Çeviri eleştirisi, kişisel beğenilere göre çeviri sonuçlarının 'olmuş' ya da 'olmamış' şeklinde değerlendirilmesi değildir. Nesnel bir çeviri eleştirisi, bir özgün ile o özgüne dayalı olarak oluşan bir çeviri metni arasında çevirmen tercihleri dışında oluşabilecek 'sapmaların', 'kaymaların' kanıtlayıcı ve örneklerle belirginleşen bir biçimde ortaya çıkarılmasını hedef alan bir karşılaştırma ve değerlendirme sürecidir. Reiß'a (1971, s. 7) göre, çevirilerin eleştirel açıdan ele alınması, "bir kültür dizgesindeki çevirilerin niteliğini arttırmakta, böylece daha iyi çeviriler, kamuoyu tarafindan talep edilir hale gelmektedir". Diğer yandan eleştiri, "dil bilincini geliştirmekte, dilsel ve dil dışı ufkumuzu genişletmektedir". Çeviri eleştirisinin yöntemleri açısından, çeviribilim araştırmaları içerisinde belirginleşmiş çeşitli kuramsal yaklaşımlardan söz etmek olanaklıdır: Bunlara, Katharina Reiß'ın (1971) 'metin-tipolojik modeli', Margrett Amman'ın (1990) 'işlevsel modeli', Juliane House'un (1997), 'edimdilbilimsel modeli' örnek verilebilir. Bu çalışmada, bu modellerin ortak noktaları, kişisel bir ele alışla değerlendirilmiş ve eleştiri, 'metin çözümlemeleri, karşılaştırma, gerekçeleri ve önerileri ile çeviri-eleştirel değerlendirmeler ve genel tutum değerlendirmesi' biçiminde düzenlenmiştir.

\section{Cahit Sitkı Tarancı}

Cahit Sıtkı, 1910'da Diyarbakır'da doğmuş̧tur. Binyazar'ın (1976, s. 4) aktardığına göre Diyarbakır'da Nümune-i Terakk-i Hamidî Mekteb-i îptidaî'ye verilmiş, bir yıl sonra Mektebi Sultanî'nin (Galatasaray Lisesi) iptida bölümüne geçmiş, böylece ilkokulu bitirmiştir. Oradan İstanbul'a gelip Saint-Joseph Lisesi'ne girmiş, daha sonra Galatasaray Lisesine geçmiştir. Galatasaray Lisesini bitirdikten sonra Mekteb-i Mülkiye'ye (Ankara Üniversitesi 
Siyasal Bilgiler Fakültesi) girmiş, oradaki başarısızlı̆̆ın ardından Yüksek Ticaret Okulu'na yazılmış, devamında çeşitli memurluklar yapmıştır. Daha sonra Cahit Sıtkı, Sciences Politiques'te okumak için Paris'e gitmiştir. Bir yandan derslerini yürütmüş, bir yandan da Paris Radyosu'nda Türkçe yayınları spikerliği yapmıştır. 2. Dünya Savaşı'nın başlamasıyla İstanbul'a dönmüştür. Askerlik görevinin ardından başka memurluklar yapmıştır. Geçirdiği bir felç sonucu tedavi için götürüldügüü Viyana'da 13 Ekim 1956'da vefat etmiştir (Krş. Ateş 1994; krş. Samanoğlu 1971, s. I-IV).

Tarancı'nın ilk şiirlerinde yayın mecraları Muhit, Servet-i Fünun ve Uyanış gibi dönemin öne çıkan dergileri olmuştur. İlk şiirlerinde duyumsanan hece ölçüsünün sınırlarına çıkan bir anlayışla dikkatleri üzerine çekmiştir. 1946'da bir yarışmada '35 Yaş' şiiri ile birincilik kazanmış ve adını duyurmuştur. Kendisine yönelik uyanan ilgi ile birlikte devrinde merakla takip edilen şairlerinden olmuştur. Garip Akımı'ndan etkilenip serbest şiiri denemiştir, diğer yandan da Baudelaire, Verlaine gibi Fransız şairlerin etkisinde kalmıştır. Şair, hayatındaki Baudelaire etkisini kendi cümleleri ile şöyle aktarmaktadır:

“... Baudelaire okuduktan sonra düşünüşüm, duyuşum, görüşüm değişti. Daha doğrusu, Baudelaire, elinde tuttuğ $u$ canlı meş'ale ile bana tutacă̆ım, tutmam gereken yolu gösterdi. Baudelaire, bana suyun dibine inmeyi öğretti. [...] Baudelaire, bana kendi kendimi buldurttu ve ben hayatımı, Baudelaire'i okuduktan önce, Baudelaire'i okuduktan sonra diye iki bölüme ayırmaktayım." (Taranc, 2003, s. 9)

Ancak, Cahit Sıtkı şiirinin oluşumunu; doğuşunu yalnızca Fransız edebiyatına dayandırmak mümkün değildir. Tarancı (2003, s. 14-15) "Baudelaire ve Verlaine'e çok şey borçluyumdur; bu şairler insana kişiliğini bulduran türden, ă̆abey ve dost şairlerdir" derken "divan şairlerinden ve halk şairlerinden de yararlandı̆̆ını, Yahya Kemal'den, Haşim'den ve daha yenilerden de yoluna ışık serpmiş olan şiirler hatırladığııı" ifade etmektedir. Zira onun şiiri, net bir biçimde bir akıma oturtulamamaktadır, daha ziyade yalın, samimi ancak bir o kadar çarpıcı dizeleri ile kendine özgü olarak nitelendirilebilir. Tüm şiirlerine genel olarak bakıldığında hece vezni taraftarı olduğu ve az sözcükle çok şey söylemeyi ideal olarak benimsemiş olduğu görülmektedir (bkz. Tarancı 2003). Samanoğlu'na (1971, s. VIII) göre onun “kurduğu mısralar nesir havası taşımaz, zorlamadan ve yapmacıklıktan uzaktır. Diyeceğini en kestirme yoldan, genellikle de az heceli kelimelerle, tek cümleden ibaret misralarla adeta konuşur gibi söyler". Bu nedenle "teşbih, istiare, mecazla pek ilgisi yoktur." Bu yalın, ancak etkili anlatım tarzının Tarancı şiirinin geniş kitlelere ulaşmasında kuşkusuz etkisi olmuştur.

Aksal (1976, s. 6) "Tarancı'nın da ölçüsüz uyaksı yeni bir anlatımı şiirinde denemek istediğini" aktarmaktadır. Ama ona göre Tarancı, bu denemeden kazançlı çıkmamıştır. Aksal'a göre "Cahit Sıtkı ölçüyle uyă̆̆n yasağından yararlanarak duygusallığını önleyebilen, ancak bu yasaklarla yoğun dizeye ulaşabilen ozanlardandı". Aksal, bu yargının bir kınama sözü gibi anlaşılmaması gerektiğine ekle şairin kendine özgü bir tutumunu belirtmekten başka bir anlama gelmediğini ifade etmektedir.

Tarancı şiirlerinde hem yaşam sevincini hem de de karamsarlığı bir arada ele almakta ve okuyucuya aktarmaktadır. Oyhan Hasan Bıldırki (1972), Hisar Dergisi'nde çıkan yazısında Tarancı'nın 'Ömrümde Sükut', 'Zaman Bir Kuşak Gibi', 'Yalnızlık Macerası' ve 'Otuzbeş Yaş' şiirlerini çözümlemekte ve "yalnızlık ve ölüm temlerinin, Cahit Sıtkı'da iç içe girmiş birer tem" olduğunu savunmaktadır. Bıldırki'ye (1972, s. 27) göre Cahit Sıtkı'da "yalnızlık, ölüme açlan bir kapıdır. Ölüm kurtuluştur, ölüm korkulu düştür, ölüm vazgeçilmez bir 
kaderdir. Ölüm asla dönüşün, Tanrı'ya erişin o güzel türküsüdür. Ölümden sonra ise yalnızlı Tanri'da devam edecek ve böylece şairin yalnızlı̆̆ı, Tanri'da baki kalacaktır."

\section{Tarancı'nın Şiiri}

Tarancı, sözcüklerin ruhunu izleyen bir şairdir. Bir sanatçı olarak şairin gereçleri olarak gördüğü sözcüklere verdiği önemi o şöyle ifade etmektedir: "Şiir sözcüklerle güzel biçimler kurmak sanatıdır, başka bir şey değildir. Ama sözcük nedir? Annedir, dosttur, kadehtir, hasrettir, hayaldir; yani bir anlamı, çağrışımı, bir gölgesi, hatta bir rengi ve adı olan nesnedir" (Taranc1, 2003, s. 21).

Bu bağlamda Tarancı, şiiri şöyle tanımlamaktadır (Taranc1, 2003, s. 17): "Şiir bir deyiştir, sözcüklerle güzel biçimleri kurmak sanatıdır". O halde şair de bu sanatı bilen adamdır. $\mathrm{Bu}$ sanatın anlatım aracı dil ve gereci de sözcüklerdir. O halde "şiir yazmak isteyen adamın kullandığı dilin bütün kurallarını iyi bellemesi" kaçınılmazdır. Ona göre şairin "sözcüklerini sımıf arkadaşlar gibi yakından tanıması, hangi sözcü̈̆̈̈n nerede ve nasıl kullanıldığı zaman kendisinden beklenen ödevi yerinde getireceğini bilmesi" önem taşımaktadır. Tarancı'nın nasıl yazarsınız sorusuna verdiği şu yanıt ilgi çekicidir:

\footnotetext{
"Nasıl yazdığımı ben de açıkça bilmiyorum, dersem şaşmayınız. Şiirde bu hiç belli olmaz.

Yemek yerken ya da yolda giderken bir dize geliverir, [...]. Bakarsinız o zamana kadar karanlık gördüğ̈̈nüz bir dünya birdenbire aydınlanmış. Artık o dize kılavuzunuz olur, yazacağını şiiri, konusunu, biçimini, boyunu bosunu, hepsini o belirler." (Taranc1, 2003, s. 14)
}

Tarancı şiiri, başka bir ifade ile onun poetikası iki düzlemde 'sözcükler' ve 'biçim' düzleminde ele alınabilir ve değerlendirilebilir görünmektedir. Sözcük seçimlerini, günlük dilin söz varlığından yararlanarak yapan Tarancı, bunu şöyle temellendirmektedir: "Konuşma dilinden ayrı bir şiir dili benim şiir anlayışıma göre olamaz. Bakın Melih Cevdet'in, Oktay Rifat'ın ve onlar gibilerin şiirlerine, hepsi sizin benim konuşurken kullandığımız sözcüklerle yazılmıştır." Onun ülküsündeki şiire giden doğru yol da budur. Nitekim kendisi şiirdeki melodinin eski(miş) sözcüklerle bezeli 'ağdalı' bir dilden geçtiği savunusunun aksine "anamın, bacımın, kızkardeşimin kullandığı dipdiri, her hecesini etimde canımda duyduğum sözcükler dururken sözlüklerde küflenmiş sözcüklerle şiir yazamam doğrusu." diyebilmiştir (Taranc1, 2003, s. 18).

Şiir söz konusu olduğunda şiire biçimini veren önemli çerçevelerden biri ölçüdür. Samanoğlu'na (1971: IX) göre "Cahit Sıtkı, daha çok, değişik bir hüviyet kazandırdı̆̆ı hece veznini kullanır, kafiyeyi silkip atmaz." Cahit Sıtkı'nın biçimi, neyin 'nasıl' söylendiği ile ilgili düzenlemeler şeklinde değerlendirdiği şu düşüncelerinden çıkarsanabilmektedir:

\footnotetext{
"...Şiirde biçimden ne anladığımı da, sırası gelmişken söyleyeyim. Söylemek istediğim şeyin-duygu, hayal, düşünce, izlenim vb.- nasıl söylemek istediğimi sezerek, keşfederek, onu o şekilde söylemeye biçim diyorum. Tabii bunun için de, anlatım aracımız olan sözcüklere gözümüz, kulă̆ımız, elimiz, ayă̆ımız imişler gibi davranmak, onları bedenimizin parçaları olarak kabul etmek gerekir. Sözcüklerle bu kadar içli dışlı olduktan sonra hangi duygunun örtülü söylenmesi, hangi düşüncenin kuvvetle dile getirilmesi, hangi hayalin kırık dökük anlatılması gerektiğini sezmek ve ona özlediği biçimi vermek biraz dikkate, biraz çalışmaya bağhldır." (Taranc1, 2003, s. 19)
} 
Bu çalışma kapsamında burada çeviri açısından değerlendirilecek olan 'Yıldızlar' ve 'Dalgın Ölü' şiirleri, Cahit Sıtkı şiirinin tipik özelliklerini taşıyan eserlerdir. Her iki eserde de Türkçenin genel söz varlığından yararlanıldığı, başka bir anlatımla şiirlerin günlük dilde var olan sözcüklerden yapılan seçimler ile kurulduğu görülmektedir. Diğer yandan bu iki eser, olumlu ve olumsuz figürlerin bir arada kullanılması açısından Cahit Sıtkı şiirinin genel özelliklerine örnek teşkil etmektedir. Cahit Sıtkı'nın bilinen tüm eserleri içerisinden bu çalışma kapsamında özgün ve çevirilerin değerlendirilmesinde söz konusu iki eserin seçimi, bu gerekçelere dayanmaktadır.

\section{Yıldızlar Şiiri ve Çevirisi}

\begin{tabular}{|l|l|}
\hline Yıldızlar & Die Sterne \\
Bazı uykum kaçtı̆̆ geceler & Manche schlaflose Nächte \\
Düşünmemek için kötü şeyler, & widme ich mich ganz der Beobachtung \\
Koşar yıldızları seyrederim & der Sterne \\
Sabahı kollayan penceremden. & aus meinem auf den Tag wartenden Fenster \\
Yıldız yoksa şaşmam düşüncemden & damit ich nicht auf schlimme Gedanken \\
Yıldızları kendim halkederim. & komme. \\
Yıldızları halketmekle geçer & Wenn auch keine Sterne zu sehen sind, \\
Bazı uykum kaçtığı geceler. & bleibe ich beharrlich bei der Sache \\
$\qquad$ Cahit Sitkı Tarancl & und denke mir dann meine Sterne aus. \\
& Manche schlaflose Nächte \\
& verbringe ich mit ausgedachten Sterne \\
& \multicolumn{1}{c}{ Çeviri: Işık Aygün } \\
\hline
\end{tabular}

\section{Metin Çözümlemeleri}

'Yıldızlar' şiirine metin işlevi açısından bakılırsa, şiirde duygu durum yaratma işlevinin ön plana çıktığı söylenebilir. Melankolik bir havanın sezildiği şiirde yalnızlık ve ölüm temalarının işlendiği görülebilmektedir. Bu noktada Binyazar'ın (1976, s. 4) Tarancı şiirlerine dönük yaptığı şu saptama yol gösterici olacaktır: "Gerek duyarlık, gerekse biçim yönünden büyük dalgalanmalar göstermez Cahit Sitkı'nın şiiri. Tersine, bir tekdüzelik gösterir. Sanki aynı şeyleri söylüyormuş gibi bir kanı da uyandırır." Binyazar bu saptamayı yaptıktan sonra şu eklemeyi / düzeltmeyi yapma gereği duymaktadır: "Ancak, zaman zaman koyu bir karamsarlık içinde boğulursunuz bu şiirleri okurken, kimi zaman da 'berrak' bir sabahla karşılaşırsınız." Eserleri genel olarak incelendiğinde öyküleyici anlatım dilinden ötürü 'akıcı' olarak nitelenebilecek Tarancı metinleri, bir yandan birbirine karşıt; daha doğrusu ve diğer yandan birbirini tümleyen ögelerin birlikte kullanımını da içermektedir.

Basılı bir kaynak olarak elimizde bulunan yukarıdaki manzum eser, çevirisi ile birlikte TÖMER Çeviri Dergisi'nin 1995 yılında çıkmış olan 5. sayısından alınmıştır. TÖMER Çeviri Dergisi, 90'lı yıllarda bir dönem üçer aylık periyotlarla yayınlanmıştır. Dergide 16 dilden yapılan çeviriler yer almaktadır. Dergide her sayıda çeviriyle ilgili kuramsal yazıların yanında hem dünya edebiyatından Türkçeye hem de Türk edebiyatından dünya dillerine çeviriler bulunmaktadır. Dergide özgün metinlerle çeviri metinler karşılıklı yer almaktadır. Dergi, 5. Sayısında yalnızlık duygusundan yıldızlara sığınışı ele alan bu şiire ve bir çeviri dergisi olduğu için çevirisine yer vermiştir. Metinsel işlevlere karşılaştırmalı olarak bakılırsa özgünde belirgin olan duygudurum yaratma işlevinin çeviri metinde manzum halinde ele 
alınmış öyküleme karakterine büründüğü görülmektedir. Dolayısı ile çeviri metne geçişte anlatımcı işlevin ağır bastığı söylenebilmektedir.

Metinler ile ilgili, başka bir söyleyiş ile özgün ve çeviri metin ile ilgili metin dışı işaretler temelinde yapılan yukarıdaki saptamalardan sonra çeviri durumuna dönük metin içi özellikler açısından şunlar belirtilebilir: Şiire ana fikir açısından bakıldığında melankolik ve bohem bir havanın ana eksende yer aldığı söylenebilir. İnsan, boş kaldığında, bir meşgalesi olmadığında ki bu durum, uyku öncesi ve sonrası belirginlik kazanmaktadır; kötü düşüncelere dalma tehlikesi ile karşı karşıya kalmaktadır. Bu anlamda engin gökyüzünün getirdiği ferahlık hissi ve yıldızlar, şaire adeta nefes aldırmaktadır. Çözümlemeyi konu akışı açısından derinleştirmek gerekirse: Şair, bazı geceler onu meşgul eden düşüncelerden dolayı uykusu kaçtığında, kötü düşüncelere kapılmamak için yıldızlara sarılmaktadır. 'Sabahı kollayan' ifadesinden uykusuz gecelerin sabahın olmaya yakınlaştığı saatlere kadar sürdüğü çıarsanabilmektedir. Şair, gökyüzünde yıldız olmasa dahi onları düşünerek düşüncesinde var etmektedir. Dolayısı ile uykusuz gecelerini yalnızca yıldızları seyrederek değil onları düşüncede var ederek de geçirdiğini dile getirmektedir. Bu anlamda yıldızları seyretmek ya da bu mümkün değilse onları düşünmek, ruhu dinlendiren, kötüyü düşünmekten alıkoyan bir eylem, bilinçli bir davranış halini almaktadır. Bu eylem, bilinç düzeyindeki bir tercihtir. Bu tercih, kötü olandan kaçış, kötü olandan iyi olana; gönlü ve ruhu eğleyici olana doğru bir sığınış biçiminde okunabilmektedir.

Gökyüzü, gök(ler) veya gökyüzü ile ilgili figürler, edebi yapıtlarda yer yer varılmak, sığınılmak istenen bir motiftir. Bu bağlamda yeryüzü âdemoğlunu ne kadar sinırlıyor, boğuyor, korkutuyor, üzüyor; kısacası kötü duygu durumların müsebbibi ya da zemini olmakta ise, gökyüzü âdemoğlunu bir o kadar, ferahlatmakta, rahatlatmakta ve mutlu etmektedir. Tarancı da gökyüzünü veya gökyüzü ile ilgili temleri kullanan ozanlardandır. 'Yıldızlar' şiirinde ise gökyüzünün temsili yıldızlar ile olmaktadır. Kaymaz (1973, s. 16), şairin 'Şaşırdım Kaldım', 'Yalan Dünya', 'Uzak Bir İklimde Gibi' eserlerini incelemiş, buradaki saptamaya koşut biçimde Tarancı'da gökyüzünün bir sığınış alanı (aracı) olduğunun ortaya çıktığını ifade etmektedir. Genel açıdan bakılacak olursa "mısraları ile çerçevelediği dünyadan, toplumdan kaçı̧ duygusu birçok şairlerde gökyüzü temi ile birlikte kullanılmıştır. Bu açıdan düşünülürse, gökyüzz̈̈; toplumda bunalanların arzuladığı bir sığınak, mutlu olunabilecek bir yerdir" (Kaymaz, 1973, s. 16). Öte yandan yine konusal olarak düşüncesinden kaçınılan kötü şeylerin ne olduğuna ilişkin bir gönderme olmayıp bu boşluk, okuyucunun hayal gücüne bırakılmaktadır. Söz konusu kötü düşünceler, bunalım, işe yaramazlık hissi, kendini suçlama, sevgisizlik, intihar düşüncesi, yalnızlık hissi gibi birçok şey olabilir.

Yapısal açıdan yapıt üç bölüme ayrilabilmekte ya da üç bölüm halinde değerlendirilebilmektedir. İlk üç mısra okuyucuya genel ve hazırlayıcı bilgiyi, 'uykunun kaçması, kötü şeyler düşünmemek için ve yıldızları seyretmek' birimleri ile vermektedir. İkinci bölümde, ilk bölümde ortaya konan / konacak eylemle ilgili bir engel ya da olumsuz durum olursa buna bağlı ikincil durum ifade edilmektedir; daha somut bir ifade ile 'yıldız yoksa o zaman ben de onları düşünürüm' denilmektedir. 'Benim dışımdaki doğa, bana bir yönüyle engel oluyorsa da, düşünce, engellenebilir bir şey değildir; düşünce her zaman vardır, var olacaktır' iletisi içkin olarak verilmektedir. Üçüncü bölümde ikinci bölümdeki düşünceden de yardım alınarak ilk bölümde anılan yıldızlara yönelme söz konusudur. Ancak bu defa aynı durumun tespiti ya da tekrarı 'seyretme' düzeyinde değil 'düşünme' 
düzeyinde yapılmaktadır. Bu bölümleme çeviri metne de yansımıştır ancak bazı mısralar farklı bir sırada bulunmaktadır.

Özgün ve çeviri metnin yer aldığı sayfada Coşkun Sami'nin 'Weightlessness' adlı çizimi bulunmaktadır. 'Hafiflik', bu bağlamda bir 'yerçekiminden muaf olma' durumudur. Bu görsel kullanımının, Cahit Sıtkı'nın '35 Yaş' şiiri ve diğer eserlerindeki 'yalnızlık', 'ölüm' ve yaş alma ile birlikte söz konusu olan 'karamsarlık' temaları açısından oldukça manidar görünmektedir.

Metinlere 'sözcükler' düzeyinde bakılırsa, Tarancı'nın 'halketmek' sözcügü dışında günlük dil kullanımını tercih ettiği görülebilmektedir. Kavramsal açıdan 'gece', karanlığı temsil etmektedir, dolayısı ile karamsarlığ imlemekte ve kötü düşünceleri çağrıştırmaktadır. Bir kavram olarak 'yıldız' ise aydınlığa, dolayısıyla yaşam sevincine kapı aralayan bir umuda, başka bir ifade ile iyimserliğe gönderme yapmaktadır. Cahit Sıtkı'nın şairliğginde yer alan 'karamsarlığı ve yaşam sevincini bir arada ele alma' anlayışı bu kutupluluk üzerinden verilmektedir. Erek metinde 'Nächte' (geceler) ile 'Sterne' (yıldızlar) uyaklı kullanımı da benzer bir kutupluluğu göstermektedir.

Metinlere sentaktik açıdan bakıldığında genel olarak şu saptamalar yapılabilir; özgünde devrik tümce kullanımlarının yoğun olduğu görülmekte iken, bu durumun çeviri metne yansımadığı görülmektedir. Bu önemli sapma ise, çeviri metni manzum bir öyküleme biçimine yaklaştırmaktadır. Son olarak biçemsel açıdan kafiye kullanımının çevri metne 'Sterne, Nächte, komme, Sache' seçimleri ile verilmeye çalışıldığı söylenebilmektedir, öte yandan metaforik anlatım tekniğinin söz konusu olduğu görülmektedir. Ayrıca şiirde ilk dize ile son dizenin tüm şiir içerisinde bulunması durumu; kısaca kavuştak, bir biçemsel figür olarak çeviri metne tam olarak yansıyamamıştır.

'Yıldızlar' Şiiri ve Çevirisi Bağlamında Çeviri Eleştirel Değerlendirmeler

\begin{tabular}{|l|l|}
\hline Bazı uykum kaçtığı geceler & Manche schlaflose Nächte \\
\hline
\end{tabular}

Tarancı'nın bir zarf tümleci olarak kullandığı 'bazı uykum kaçtığı geceler' dizesi, Almancada 'manche schlaflose Nächte' biçiminde yani -i hali ile kurulmuş zaman zarfı olarak karşılık bulmuştur. Kabul edilebilir bir çevirmen tercihidir.

\begin{tabular}{|l|l|}
\hline Koşar yıldızları seyrederim & widme ich mich ganz der Beobachtung der Sterne \\
\hline
\end{tabular}

'Koşar yıldızları seyrederim' tümcesi 'widme ich mich ganz der Beobachtung der Sterne'; yani ‘kendimi yıldızları seyretmeye (gözlemlemeye) adarım' anlamı ile karşılanmış. Bu tümcede 'koşar' yüklemi, geniş zamanlı kurulduğu için 'alışkanlık' içerimine gönderme yapmaktadır. Buradaki 'alışılagelme' veya 'rutin' içeriği, Almancadaki 'sich widmen', 'kendini bir şeye adamak, vakfetmek' fiilinin kullanımı ile verilmeye çalışılmıştır. 'Vakfetme', 'bir şey ile sıkça vakit geçirme' şeklinde bir anlam alanına sahip olduğundan, bu çevirmen tercihi, yine kabul edilebilir görünmektedir.

\begin{tabular}{l|l} 
Sabahı kollayan penceremden. & aus meinem auf den Tag wartenden Fenster
\end{tabular}

'Sabahı kollamak', somut anlamda 'sabahı beklemek' olsa da, 'kollamak' sözcüğünde olumlu gerçekleşeceği tahmin edilen bir şeyin beklenmesi anlamı vardır. Şairi karamsarlığa iten gecedir, bu anlamda 'pencere' ile kastettiği şeyin aslında kendisi olduğu; diyesi bir kişileştirmeye gidildiği yorumu yapılabilir. Zira bir obje; eşya, bir şeyin olmasını, gerçekleşmesini sabırsızlıkla bekleyemez. Burada 'fırsat, şans' gibi olumlu yüklü isimlerle 
kullanılan 'kollamak' fiili karşıllğı olarak 'warten' tercihi, olumlu anlamı nötrleştirmektedir. Simgesel açıdan 'sabah'ın olumlu açıdan yorumlanabilirliği şurada yatmaktadır. Sabah, gecenin son bulması, gündüzün temsilidir. Gündüz ise, iyimserliğin, yaşama sevincinin temelidir. Dolayısı ile Tarancı, sabahın olmasını içten içe de istemektedir. Kişileştirme atlanarak somuta, başka bir ifade ile daha düz bir anlatıma gidildiği için bu çevirmen tercihi eleştirilebilir görünmekte, 'warten' fiili yerine 'abwarten' ya da 'suchen' fiilleri ile çözüm üretilebilmektedir. Öte yandan yine bu tümcede yer alan 'sabahı' ile gündüz kastedildiği için, gece ile gündüz bir kutupluluk içinde değerlendirilirse üretilen 'auf den Tag' karşıllı̆̆ı, kabul edilebilir görünmektedir.

Düşünmemek için kötü şeyler

damit ich nicht auf schlimme Gedanken komme.

'Kötü şeyler düşünmemek', açıklayıcı biçimde 'kötü düşüncelere kapılmamak' anlamıyla verilmektedir. Zira 'düşünmek' karşılığı olarak ilk olarak akla gelebilecek 'denken' ya da 'überlegen' fiilleri, farklı bağlamlarda da anlaşılabileceği için çevirmenin yaptığı bu açıklama, yerinde bir tercihtir. Çünkü 'denken' ve 'überlegen' fiillerinde bilinçli bir eylem söz konusu iken 'düşüncelere kapılmak' istemsiz gerçekleşmektedir. Şairin sonraki bölümlerde kullandığı 'halketmek' fiili ise, tam da bilinç düzeyinde gerçekleşen bir eylemdir. Anlamı ise sonraki bölümlerde tartışılacaktır.

\begin{tabular}{|l|l}
\hline Yıldız yoksa şaşmam düşüncemden & Wenn auch keine Sterne zu sehen sind,
\end{tabular} bleibe ich beharrlich bei der Sache

Özgünde hissettirilen yıldızların görünür olmamasındaki çaresizlik 'keine zu sehen sind' şeklindeki yapı ile verilmeye çalışılmış, buna rağmen 'ısrarla konunun içerisinde kalmak' olarak Türkçeleştirilebilecek 'beharrlich auf der Sache bleiben' ifadesi kullanılarak benzer bir çaresizlik durumu, bir çözüm içeriği olarak verilmeye çalışılmıştır.

'Beharrlich bei der Sache bleiben' yapısı, 'israrla bir konuda, esas meselede kalmak, o şeye odaklanıp başka bir şeye yönelmemek' içerimi ile tercih edilmiştir. Özgündeki ‘şaşmam düşüncemden' eylemi, 'düşünmekten vazgeçmem' alt anlamı ile kullanılmıştır. Bu noktada erek kültür açısından; başka bir söyleyişle Alman okuru için yalnızca 'bei der Sache bleiben' eksik kalabilirdi, bu nedenle 'beharrlich' (1srarla) eklemesi yapılarak, 'ne olursa olsun bir şeyden çıkmama, yılmama' anlamı yakalanmaya çalışılmış ve çözüm bir pekiştirme ile bulunmuştur. Bu bağlamda anlamı kuvvetlendirmeye dönük bu çevirmen hamlesi ile yukarıdaki tümce kabul edilebilir görünmektedir.

\begin{tabular}{|l|l|}
\hline Yıldızları kendim halkederim. & und denke mir dann meine Sterne aus. \\
Yıldızları halketmekle geçer & Manche schlaflose Nächte \\
Bazı uykum kaçtığı geceler. & verbringe ich mit ausgedachten Sterne \\
\hline
\end{tabular}

'Halketmek', var ermek; yaratmak demektir. Şair bu sözcüğü, belli bir bilinç ile seçerek kullanmaktadır. Bunu, 'madem yıldız yok, onları zihnimde yaratırım öyleyse' demek için yapmaktadır. 'Halketmek' karşılığı olarak çevirmen bir yerde 'ausdenken' fiilini 1. tekil şahsa göre geniş zamanda çekimleyerek verirken, başka bir yerde ortaçlı yapı ile sıfat olarak 'ausgedacht' (Partizip II) biçiminde kullanmaktadır. 'Tasarlamak, uydurmak, tasavvur etmek' anlamları ile 'ausdenken' fiili makul bir tercih olmakla birlikte bunun yerine anlamı düşünmekten çok hayal etmeye daha yakın 'vorstellen' fiili bir başka seçenektir. Zira şair bir kere 'uydurmuş, yaratmış'tır ve bu durum geçmiştir, devam eden asıl eylem artık 
'tasavvur etmek', başka bir anlatımla bir şeyi zihninde var etmektir. Diğer yandan özgünde olmamasına rağmen, şair tarafından uydurulan / uydurulmuş yıldızların 'meine' (benim) iyeliği ile vermesini de, bu anlamı pekiştirmek için alınmış bir önlem olarak değerlendirmek mümkündür.

\section{Genel Tutum}

Cahit Sıtkı'nın 'Yıldızlar' adlı şiirinin çevirmen Işık Aygün tarafından yapılan çevirisine genel açıdan bakıldığında, çevirmenin Tarancı'nın kafiyeli ve manzum anlatım biçimini, daha düz yazıya yakın; yani melodi eksiklikleri bulunan bir dille aktardığı saptamasını yapmak olanaklıdır. Bu yönü ile çeviri, biçimsel açıdan üzerinde çalışılabilir nitelikte olsa da, içerik açısından Tarancı'nın ana fikrinin çeviriye yansıdığını, anlamın korunmaya çalışıldığı kuşkusuz söylenebilecektir.

\section{‘Dalgın Ölü' Şiiri ve Çevirisi}

\begin{tabular}{|c|c|}
\hline $\begin{array}{l}\text { Dalgın Ölü } \\
\text { Dün güzel bir kadın geçti } \\
\text { Kabrimin yakınından } \\
\text { Doya doya seyrettim } \\
\text { Gün hazinesi bacaklarını } \\
\text { Gecemi alt üst eden } \\
\text { Söylesem inanmazsınız, } \\
\text { Kalkıp verecek oldum } \\
\text { Düşürünce mendilini } \\
\text { Öldüğümü unutmuşum. }\end{array}$ & $\begin{array}{l}\text { Der unaufmerksame Tote } \\
\text { Eine schöne Frau ging gestern } \\
\text { An meinem Grab vorbei. } \\
\text { Mit Herzenslust betrachtete ich } \\
\text { ihre wunderschönen Beine } \\
\text { die meiner Nacht wieder Leben geben. } \\
\text { Ihr werdet mir nicht glauben aber } \\
\text { beinahe wäre ich aufgestanden } \\
\text { um ihr Taschentuch zu geben, } \\
\text { als sie es versehentlich fallen ließ. } \\
\text { Ich hatte vergessen, dass ich gestorben war. } \\
\qquad \text { Çeviren: Işık Aygün }\end{array}$ \\
\hline
\end{tabular}

\section{Metin Çözümlemeleri}

Metin dışı faktörler açısından ‘Dalgın Ölü' şiirinin çevirisine ilişkin 'Yıldızlar' şiirinin çevirisine ilişkin yapılan saptamalara benzer saptamalar yapılabilmektedir. Zira ilgili şiirin çevirisi, yine TÖMER Çeviri Dergisi'nin 1995 yılında çıkmış olan 5. sayısından alınmıştır. Tarancı'nın bu şiirinde öyküleyici bir anlatım tarzı söz konusudur. İlk dizeden itibaren sırası ile bir olay anlatılmakta ve okuyucunun ilgisi ve merakı olayın akıbeti yönünde çekilmektedir. Çevirisi açısından bakılırsa bu metin işlevinin daha da ileri götürülerek düz yazı çizgisine yaklaştığı tespitini yapmak olanaklıdır.

Özgün ve çeviri metnin yer aldığı sayfada Max Klinger'in 1878 tarihli çizimi 'Phantasien über einen gefundenen Handschuh' (Bulunan Bir Eldiven Üzerine Fanteziler) bulunmaktadır. Bu görsel kullanımı, şiirin teması açısından oldukça manidar görünmektedir.

Metin içi faktörler açısından ise şu genel saptamalarla başlamak, yerinde olacaktır: Şiirde bir 'ölü' olarak Tarancı'nın hayata duyduğu özlem, canlı olana duyduğu ilgi anlatılmaktadır. Bu bağlamda şiir 'hayata el uzatmak, ulaşmak isteyerek ona uzanmak ancak ulaşamamak' hissi uyandırmaktadır. Hayat ise, 'güzel bir kadın' üzerinden resmedilmekte, kadın imgesi hayatı imlemektedir. 
Binyazar'a (1976, s. 4) göre "insanın varliğına inanması ve yokluğunun bilincine varması ikilemi, Cahit Sıtkı'nın şiirinin temelini oluşturan ana öğelerden biridir." Bu bağlamda Tarancı'nın başkaca şiirlerinde de işlediği görülen 'ölüm' teması, burada da açık biçimde görülmektedir. Ancak bu kurgu içerisinde güzel bir kadın üzerinden anlatılan canlılık bir tarafta, kendisi üzerinden anlattığı ölüm ise, bir diğer tarafta durmaktadır. Yaşam ile ölüm arasındaki çarpıcı fark; etkileyici bir ayrım olarak son üç dizedeki 'imkânsızlık, çaresizlik' kavramları yoluyla okuyucuya aktarılmaktadır.

İçerik açısından bir ölünün 'dalgın' sıfatı ile nitelendirilmesi, ilk tahlilde oldukça ironik görünmektedir. Şair kendini 'ölü' olarak tanımlamakta ise de, 'unutma', 'unutkanlık' tam da bir beşer halidir. Yaşam ve ölüm temleri ile çizilen bu kutupluluk, bu göstergeler üzerinden dile gelmektedir. Şiir temelde iki bölüm halinde ele alınabilir. İlk bölümde ölümün bilgisi, 'kabir' sözcügü ile verilmekte iken, ikinci bölümde 'ölmek' sözcüğü üzerinden verilmektedir. Bunun karşısında hayatın temsili, ilk bölümde 'kadın', ikinci bölümde 'mendil' imgeleridir. İlk 5 mısra, ilk bölüm olarak değerlendirilebilir ve aktarılan olay, şiire giriş durumudur. Sonraki 4 mısra ise şiirin sonuca bağlandığ ikinci bölüm olarak ele alınabilmektedir.

Ozansoy'a (1964, s. 11) göre “Cahit Sıtkı'nın dili kadar düşünce unsurları da eserine zaman dışı bir değer sağhlyacak niteliktedir. Yaşama sevinci, ölüm gerçeği, insan ve tabiat sevgisi, yok olmak korkusu, kendini yalnız hissetme, geçen zamanl, başka dünyaları arayış..." Buna benzer saptamalar, Cahit Sıtkı'yı karamsar bir şair gibi betimlese de Cahit Sıtkı'yı, karamsar olmaktan ziyade gerçekçi bir ozan olarak tanımlamak yerindedir. Batı kaynaklı varlık felsefesi açısından ölüm, yaşam ile birlikte ele alınan, onun kadar doğal bir olaydır. Tasavvufi açıdan da bir zorunlu istikamet, vuslata açılan bir kapıdır. Binyazar (1976, s. 4), "Cahit Sıtkı'nın şiirinde -hemen her şiirinde- belirenin, aslında ölüm korkusu değil, var oluşun gerçe⿻̆gi" olduğunu savunmaktadır. Bu anlamda "ölüm, ölümün kendisinden öte, yaratılan bir duygu dünyasıdır, ölümün şiire dönüşümüü̈r'”. Binyazar'ın tespitlerine göre 'Taranc1, ölümün karşısında yaşamı coşkuyla koyar, bu anlamda yaşam adeta ölüme dönüş sürecidir. Gizemcilerin 'varlık birliği' görüşü, Cahit Sıtkı'da, şiirleşen bir öğedir. Bu anlamda insan bir devr'i daimin (sürekli dönüşümün) bir zerresidir. Cahit Sıtkı'nın şiiri, bu 'zerre' oluş bilincine varan bir şiirdir. Ozanın zaman zaman işlediği yalnızlık, karamsarlık, sığınma duygusu, yaşam sevinci... Binyazar'a (1976, s. 4) göre bu konuların hepsi hep bu temel amaçtan kaynaklanmaktadır.

\section{‘Dalgın Ölü’ Şiiri ve Çevirisi Bağlamında Çeviri Eleștirel Değerlendirmeler}

\begin{tabular}{|l|l|}
\hline $\begin{array}{l}\text { Dün güzel bir kadın geçti } \\
\text { Kabrimin yakınından }\end{array}$ & $\begin{array}{l}\text { Eine schöne Frau ging gestern } \\
\text { An meinem Grab vorbei. }\end{array}$ \\
\hline
\end{tabular}

İlk iki dizede manzum eserler söz konusu olduğunda 'Türkçe-Almanca' dil çiftinde yakalanması oldukça zor bir koşutluk, daha açık bir söyleyişle içerik ve biçim açısından bir eşdeğerlik yakalanmıştır.

\begin{tabular}{|l|l}
\hline Doya doya seyrettim & Mit Herzenslust betrachtete ich
\end{tabular}

'Mit Herzenslust' ifadesi 'gönülden isteyerek, kalpten gelen bir istekle' anlamina gelmektedir. Bu ifadenin içeriminde 'akıl' yok 'kalp' vardır. Dolayısı ile bu istek, karşı konulamaz ve kontrol edilemez bir istektir. Oysa özgündeki 'doya doya seyretmek', 'bir daha bulunması çok da mümkün olmayacak bir fırsatı, bir olanağı değerlendirerek 
seyretmek' demektir. Başka bir anlatımla 'doya doya' ikilemesi, 'doymak' fiilinden gelmektedir ve 'bir gereksinimini yeteri kadar karşılamak' ya da 'yeter bulmak, kanmak, tatmin olmak' anlamlarına gelmektedir. Nitekim benzer biçimde 'kana kana' şeklinde bir ikileme de söz konusudur. Buradaki zarf ihtiyacı 'in vollen Zügen genießen' yapısında görülen 'in vollen Zügen' yani 'tamamen, sonuna kadar' gibi bir anlama gelecek şekilde yeniden düzenlenebilmektedir.

\begin{tabular}{|l|l}
\hline Gün hazinesi bacaklarını & ihre wunderschönen Beine \\
\hline
\end{tabular}

'Gün hazinesi bacaklarını' öbeği, 'ihre wunderschönen Beine' tamlaması ile verilmektedir. Tarancı'ya ait bu özel tabirin çevirisi için bir çevirmen araştırması gerekli görünmektedir. Bu açıklama Ziya Osman Saba'da bulunmaktadır. Saba, 'Cahit Sıtkı'nın, bir şiirinde 'gün hazinesi' dediği bacakların uzun konçlu şosonlarda hapsetmiş bir ömür hazinesi genç kızlar var' dediğini aktarmaktadır. Konç, 'ayağa giyilen şeylerde ayak bileğinden baldıra doğru olan bölüm', şoson, kumaş veya ince deriden, çoğunlukla düz topuklu, ayağı bütünüyle saran ayakkabı'dır. Dolayısıyla 'gün hazinesi', 'bir hazine gibi üstü örtülmüş; saklanmış' anlamında değerlendirilebilecektir. Bu tümcenin çevirisinde, bu bilgiden hareketle 'ihre Beine wie ein Schätzchen' ya da 'ihre Beine wie einen versteckten Schatz' şeklinde bir düzenleme yapılabilmektedir.

Gecemi alt üst eden die meiner Nacht wieder Leben geben.

'Gecemi alt üst eden' yapısına karşılık olarak çeviri metinde 'die meiner Nacht wieder Leben geben' yani 'geceme yeniden hayat veren' anlamina gelen bir yapı tercih edilmiştir. Bu tercih, kabul edilebilir niteliktedir, zira burada 'alt üst etmek', olumsuz değil olumlu bir anlam yükü ile kullanılmaktadır. O halde bu ifade, 'karıştırmak, darmadağın etmek' şeklinde olumsuz bir bağlamda ele alınamayacaktır. 'Genç kadın' imgesinin genel anlam olarak 'hayat'ı temsil ettiği düşünülürse, bu çevirmen çözümünü, kabul edilebilir; hatta yerinde olarak değerlendirmek olanaklıdır.

Kalkıp verecek oldum beinahe wäre ich aufgestanden

'Kalkıp verecek oldum' yapısı, Almancada 'az kalsın kalkıyordum' biçimi ile verilmektedir. Konjektiv II yapısı ile birlikte kullanılırsa kazandığı 'az kalsın' anlamı ile ‘beinahe' kullanımı, kabul edilebilir bir çevirmen çözümüdür.

\begin{tabular}{|l|l|}
\hline Düşürünce mendilini & als sie es versehentlich fallen ließ.
\end{tabular}

'Mendilini düşürmek' ifadesine çeviri metinde 'versehentlich' (bilmeden, yanlışlıkla, dalgınlıkla) eklemesi, yerinde olmamıştır. Zira bir figür olarak kadının mendilini yanlışlıkla düşürdüğü çıkarımı yapılması olanaksız görünmektedir. Kültürel arka planda mendil bir şifre olarak değerlendirilebilmektedir. Kültürümüz açısından mendil, aşıklar arasında bir iletişim aracı olmuştur. Mendilin yere atılması, bir ilanı aşk olabileceği gibi, mendilin alınıp sahibine verilmesi ya da verilmemesi birer iletişime geçme biçimi olarak yorumlanabilmektedir. Dolayısı ile Tarancı'nın mendil düşürme sahnesini belli bir bilinç ile kullanma olasılı̆̆ın çevirmen olarak gözden ırak tutmamak gerekmektedir. Aksi halde, eşdeyişle Tarancı şiirine 'yanlışlıkla' mendil düşürme eklemesi yapılırsa, onun kurgusuna etki etme tehlikesi doğmaktadır. 


\section{Genel Tutum}

Tarancı'nın 'Dalgın Ölü' şiirinde genel olarak anlatımcı, başka bir deyişle öyküleyici bir anlatım dikkati çekmektedir. Tarancı baştan itibaren bir olay anlatmaya başlamaktadır ve devamı ile ilgili okuyucuyu merakta bırakmaktadır. Çevirisi açısından çevirmenin bu öykü tadını koruduğu söylenebilmektedir.

\section{SONUÇ}

Cahit Sıtkı, yalın ve içten anlatımı ile geniş kitlelere seslenebilen bir ozandır. O, bu başarıma yalnızca üsluptaki sadeliği ile değil, geliştirdiği kendine özgü şairliği ile de ulaşmaktadır. Bu şairlikte ne uyak tümüyle reddedilmekte ne de serbest şiir tam anlamıla onaylanmaktadır. Döneminde yapılan ve bir taraf seçme ile sonuçlanan çeşitli edebiyatkuramsal tartışmalardan bağımsız olarak sözcüklerin gücüne inanan Tarancı, şiir sanatının yaratım gücünü, sözcüklerin düzenlenişinde görmüştür. Sanatını iç dünyasının belirlediğini yer yer ifade etmesine rağmen, adeta konuşur gibi söylemesi ile de halka dokunmuştur. Konusal açıdan ele aldığı 'ölüm' kavramı sevimsiz bir seçim gibi görünse de, bu ele alış bir seçim değil, bir dışavurumdur. Dolayısıyla o ne hissettiyse, ne düşündüyse onu yazmıştır.

Şiirlerinin Almancaya aktarılabilirliği konusunda burada yapılan çalışma, uyaklı anlatım saplantısı görülmeyen Tarancı şiirlerinin, bu biçimsel serbesti nedeniyle çeviride kabul edilebilir sonuçlar verdiğini göstermektedir. Ancak bu, onun şiirlerinin çevirisine 'düzyazı' gibi yaklaşılabileceği anlamına gelmemektedir. Bu anlamda şiir dili açısından üslubu belirleyen bir unsur olarak dikkati çeken sentaktik yapının çeviride koşut bir şiirselliği sağlayacak biçimde yansıtılamaması, estetik etkiyi sekteye uğratabilmektedir. Bu yüzden şiirselliği, başka bir anlatımla estetik etkiyi engelleyen yöntemsel tutumlardan mümkünse kaçınılması gerekir. Tarancı'nın Türkçede yaptığı, doğru sözcük seçimlerini yapmak ve bunları etkili ve melodik biçimde ait oldukları yerlere koymaktır. Bunu çoğu zaman, genel kurgusu içerisinde kendisinin çok iyi bildiği ve belirlediği bir dozajda, başka bir anlatımla uygun oranda kullandığı uyaklı sözcük seçimleri ve devrik tümce yapıları ile sağlamaktadır. Dolayısı ile Tarancı'nın yer verdiği uyaklı ve devrik anlatım unsurlarının oranına dikkat edilerek Almancada nispi açıdan yüksek eşdeğerlikli çeviri sonuçlarına ulaşılmaktadır.

\section{SUMMARY}

Cahit Sitkı is one of the poets who has been able to establish a sincere communication with a wide audience in Turkish Literature with a formally simple expression style. However, this simplicity in form did not banalize his poetry aesthetically. Because of his unique style, the structure of his poems and the fiction that he reflects on the words he chooses have enabled him to present the subjects he has dealt with strikingly. In this respect, his poems represent literary phenomenon cases, which are worthy to be examined in academic terms. On the other hand, approaching Taranc1 poems, especially in languages which are not close to each other in terms of structure, in the context of poetry translation, which is often described as a difficult or even doomed attempt to fail, has been understood as a subject worthy of examination. In this study, first of all, the features framing the form, style and themes of Taranc1 in theoretical terms have been attempted to be found and all his works have been evaluated from these aspects. Based on this evaluation and the opinions gathered in a descriptive manner, the following determinations could be made. 
Formally, in Taranci's poetry, neither rhyme is completely rejected nor free poetry is fully confirmed. Taranc1, who has adopted the principle of expression as if he were speaking, did not prefer to use a splendid language, which is very much associated with art and even rejected it. Cahit Sitkı Taranc1 is characterized thematically by his most widely known poem ' 35 Yaş' (Age 35) today and he is described as 'the poet of death'. Although 'death' is one of the main themes shaping Cahit Sitki's poetics, when all his works are evaluated in terms of thematic aspect, it is seen that 'life', which is dealt with 'death', is also in question. Taranc1, who blends pessimistic elements with optimistic elements in his poems in a subtle way, is a poet who tries to convey his themes through polarity by using the concepts he pursues.

In the practical part of the study, the translation situations including two Taranc1 poems, 'Yıldızlar' (Stars) and 'Dalgın Ölü' (The Pensive Dead), containing similar themes and in fact a polarity, are examined. These poems and their translations into German were analyzed on the basis of a translation-oriented text analysis approach and were presented comparatively in the light of the features of Cahit Sitki's poetry. Comparisons were made in the light of the data arising from the analysis and original texts and translation texts were attempted to be analyzed critically. As a result of the study, Taranc1 poems, which do not always contain rhyming narrative, have shown that because of this formal flexibility, they can be transferred to German with acceptable responses. What Taranc1 does in Turkish is to make the right word choices and put them effectively and melodically in their places. This is often accomplished with rhyming word selections and inverted sentence structures he uses at a dosage that he knows and determines very well within his general construct, in other words, at an appropriate rate. By taking into account the proportion of rhyming and inverted narrative elements that Tarancı uses, relatively high equivalent translation results are achieved in German. 


\section{KAYNAKÇA}

Aksal, S. K. (1976). Arkadaşlarının anılarından Cahit Sıtkı Tarancı. Milliyet Sanat Dergisi, 200, s. 6-9.

Ammann, M. (1990): Anmerkungen zu einer Theorie der Übersetzungskritik und ihrer praktischen Anwendung. Zeitschrift TEXTconTEXT (5.3/4), s. 209-250.

Ateş, M. (1994.10.13). İz bırakanlar: Cahit Sıtkı Tarancı. Hürriyet Gazetesi.

Bezirci, A. (2003). "Sunu”. Otuz Beş Yaş-Bütün Şiirler. Cahit Sıtkı Tarancı. İstanbul: Can Yayınları.

Bıldırki, O. H. (1972). Tarancı'da yalnızlık ve ölüm. Hisar Dergisi, 106, s. 26-27.

Binyazar, A. (1976). Cahit Sıtkı'nın şiiri gerek duyarlık, gerek biçim yönünden büyük dalgalanmalar göstermez. Milliyet Sanat Dergisi, 200, s. 4-5.

House, J. (1997). Translation quality assessment: a model revisited. Tübingen: Narr Verlag.

Kaymaz, R. (1973). Tarancı'nın şiirinde toplumdan kaçış: Gökyüzü temi. Hisar Dergisi, 118, s. 16-17.

Nord, C. (1988). Textanalyse und Übersetzen. Theoretische Grundlagen, Methode und didaktische Anwendung einer übersetzungsrelevanten Textanalyse. Heidelberg: Groos.

Ozansoy, M. F. (1964). Düşündüğüm gibi: Cahit Sttkı Tarancı. Hisar Dergisi, 86, s. 10-11

Reiß, K. (1971). Möglichkeiten und Grenzen der Übersetzungskritik. Kategorien und Kriterien für eine sachgerechte Beurteilung von Übersetzungen. München: Hueber Verlag.

Samanoğlu, G. (1971). Cahit Sıtkı Tarancı. Hayatı, şiiri ve eserleri hakkında birkaç söz. Seçmeler. Birinci Basılış. Cahit Sıtkı Tarancı. İstanbul: Milli Eğitim Basımevi.

Tarancı, C. S. (1971). Seçmeler. Birinci Basıllş. haz. Gültekin Samanoğlu. İstanbul: Milli Eğitim Basımevi.

Tarancı, C. S. (2003). Otuz Beş Yaş. Bütün Şiirleri. Der. Asım Bezirci. İstanbul: Can Yayınları. 22. bs.

Tarancı, C. S. (2012). Gün eksilmesin penceremden. İstanbul: Can Yayınları

TÖMER Çeviri Dergisi (1995). Cahit Sıtkı Taranc1, 5, s. 50-51. 